University of Nebraska - Lincoln

DigitalCommons@University of Nebraska - Lincoln

Mammalogy Papers: University of Nebraska

State Museum

Museum, University of Nebraska State

April 1967

\title{
Taxonomic Status of the Brush Mouse, Peromyscus boylii cansensis Long, 1961
}

Jerry R. Choate

University of Kansas, Lawrence

Carleton J. Phillips

University of Kansas, Lawrence

Hugh H. Genoways

University of Kansas, Lawrence, h.h.genoways@gmail.com

Follow this and additional works at: https://digitalcommons.unl.edu/museummammalogy

Part of the Zoology Commons

Choate, Jerry R.; Phillips, Carleton J.; and Genoways, Hugh H., "Taxonomic Status of the Brush Mouse, Peromyscus boylii cansensis Long, 1961" (1967). Mammalogy Papers: University of Nebraska State Museum. 61.

https://digitalcommons.unl.edu/museummammalogy/61

This Article is brought to you for free and open access by the Museum, University of Nebraska State at DigitalCommons@University of Nebraska - Lincoln. It has been accepted for inclusion in Mammalogy Papers: University of Nebraska State Museum by an authorized administrator of DigitalCommons@University of Nebraska Lincoln. 


\section{Taxonomic Status of the Brush Mouse, Peromyscus boylii cansensis Long, 1961}

JERRY R. CHOATE, CARLETON J. PHILLIPS, and HUGH H. GENOWAYS

In the course of a study of mammals from southeastern Kansas and northeastern Oklahoma, the authors have collected specimens of the brush mouse, Peromyscus boylii cansensis Long, from its type locality and also from a place about 16 miles southwest of the type locality. The results of studies of these specimens, and of the holotype and paratypes of the subspecies, are presented and discussed herein.

Long (1961:101) named Peromyscus boylii cansensis from specimens obtained in Chautauqua and Cowley counties of Kansas. He thought it was geographically isolated from Peromyscus boylii attwateri, which is known from farther to the east in Kansas, as well as from southwestern Missouri and northwestern Arkansas, southwestward through Oklahoma to Texas (see Hall and Kelson, 1959:634). According to Long (1961: 101-102), cansensis differs from attwateri as follows: less protuberant eyes; shorter tail (91 versus 103 per cent of length of head and body); darker pelage; and longer skull and nasals.

\section{Methods and Materials}

Fifty-six specimens of Peromyscus boylii cansensis were collected on 20 March 1966 from rocky bluffs along the Caney River, 1 mi. N, 21/4 mi. W Elgin, Chautauqua County, Kansas. These specimens and 27 specimens of $P . b$. cansensis (including holotype and paratypes) deposited previously in The University of Kansas Museum of Natural History were compared with 20 specimens of $P . b$. attwateri from southeastern Kansas, from Missouri and Arkansas, and from $3 \mathrm{mi}$. W Mason, Mason County, Texas (only 50 miles from the type locality of the subspecies). Three live specimens of cansensis $(2 \hat{\delta}, 1 q)$ from Chautauqua County and one live male of attwateri from Cherokee County, Kansas, all adults, were collected and examined for degree of protuberance of eyes. All specimens were examined and classified according to age. Criteria used for classification of age, as stated below, were modified slightly from those used by Hoffmeister (1951:1) for Peromyscus truei:

juvenile-M3 unworn;

young-lingual cusp of M3 worn; M1 and M2 showing little or no wear;

Transactions of the Kansas Academy of Science, Vol. 69, Nos. 3-4, 1966. Published April 25, 1967. 
subadult-M3 worn smooth; lingual cusps of M1 and M2 worn but labial cusps showing little or no wear; adult-lingual cusps of M1 and M2 worn away and labial cusps showing considerable wear.

Unless noted otherwise, all measurements herein are in millimeters. The external measurements used were taken from fresh specimens prior to skinning by one or another of the three authors, and cranial measurements were taken by one of the authors (Phillips). Definitions of cranial dimensions used here, as well as techniques for taking them, are from Hall (1946: 672-685). All capitalized color nomenclature is from Ridgway (1912). Most specimens listed by us are deposited in The University of Kansas Museum of Natural History (KU). We thank E. Raymond Hall and J. Knox Jones, Jr., for the use of these specimens and for reviewing the manuscript. We also thank Horace A. Hays of the Department of Biological Sciences, Kansas State College (KSC) for loaning specimens of $P$. boylii attwateri in his care and for other assistance. Elmer C. Birney, Charles L. Douglas, and Joyce E. Genoways kindly assisted with various phases of the study.

\section{Results}

Measurements of tail vertebrae of our 59 specimens of $P$. boylii cansensis of all ages are given in a scatter diagram (see Figure 1). These specimens were collected 16 miles southwest of the type locality of cansensis. In adults, the tail (caudal vertebrae) is at least as long as the head and body; the average length of tail is 103 per cent of the length of head and body. In our two juveniles and in one subadult, the tail is longer than the head and body; in three subadults the tail is as long as the head and body; in 42 subadults the tail is shorter than the head and body.

Length of nasals was plotted against greatest length of skull (Figure 2 ). This scatter diagram, in which measurements of adults of $P . b$. attwateri from Texas, Missouri, Arkansas, and southeastern Kansas are included with measurements of adults of cansensis, shows that no distinction can be made between the two "subspecies" on the basis of length of nasals or greatest length of skull. Additional cranial measurements (mean, standard error of the mean, and range) of adults are presented in Table 1, from which it can be seen that adults of the four samples from four states are essentially the same size. Crania of attwateri from Texas are only slightly smaller than those of cansensis from Chautauqua and Cowley counties, Kansas. Mean of greatest length of skull in attwateri is 28.6 and in cansensis is 28.8 , but the mean given for attwateri (28.6) is 
larger than the mean of the type and paratypes of cansensis (28.3) given by Long $(1961: 102)$. Mean length of nasals of specimens from Texas is 10.4 and mean length of specimens from Kansas is 10.6. Here the mean for attwateri (10.4) is exactly the same as the mean for 11 specimens of cansensis that Long (1961:102) measured.

Examination of three live specimens of cansensis and one of attwateri revealed no difference in degree of eye protuberance, nor did examination of freshly skinned specimens reveal any such difference.

Subadults from Chautauqua County are Dark Mouse Gray to Dark Neutral Gray on the upper parts and Ochraceous-Buff on the sides; adults are Buckthorn Brown to Dresden Brown on the upper parts and Ochraceous-Tawny on the sides. Upper parts of the holotype of cansensis, which was in process of molting from subadult to adult pelage when prepared, are Mummy Brown. Winter pelage of adults from Texas is slightly paler than that of specimens from Kansas. This is due to Light Buff tips on hairs of the dorsum of mice from the southern locality.

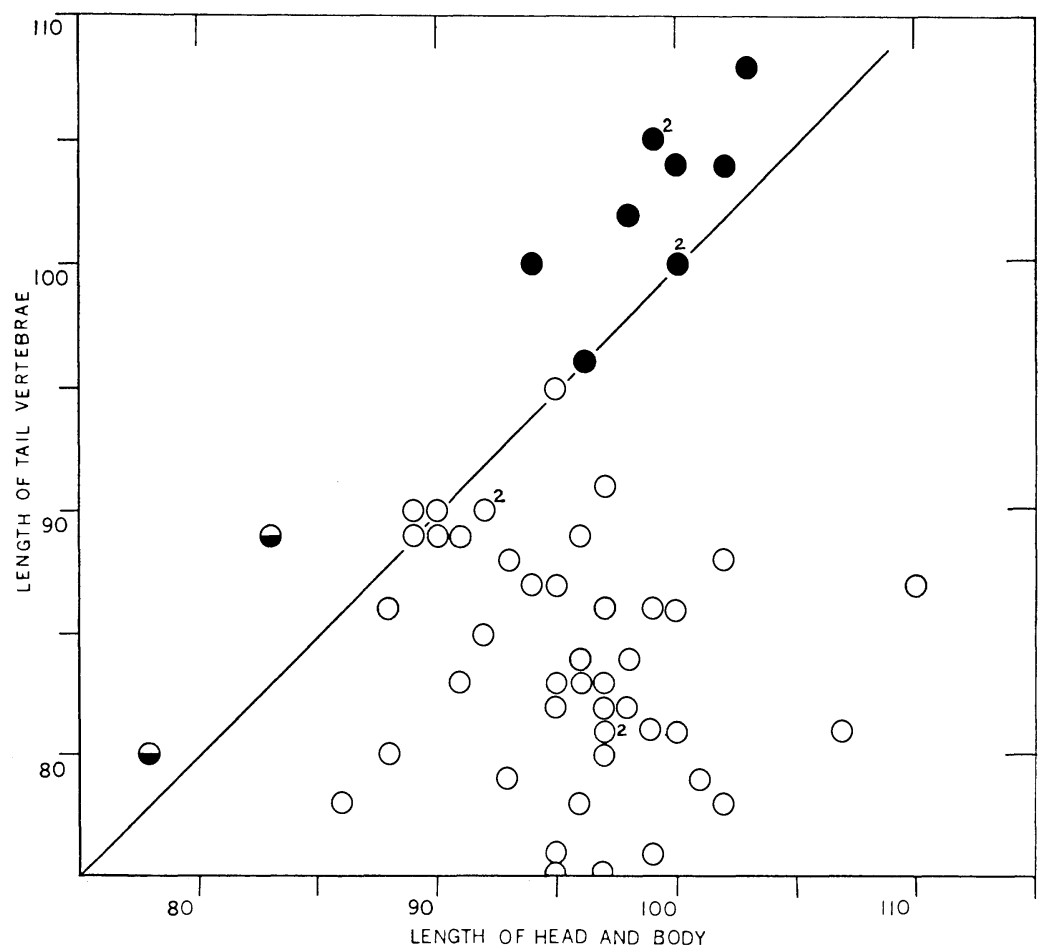

Figure 1. Comparative measurements, in millimeters, of adults (solid circles), subadults (open circles) and juveniles (half-closed circles) of Peromyscus boylii from Chautauqua County, Kansas. Numbers indicate more than one specimen represented by circle. 
Even so, the general coloration of the upper parts of adults of $P$. boylii from Texas is near (16l) Mummy Brown.

\section{Discussion}

During late subadulthood, and perhaps in early adulthood, the length of the tail in $P$. boylii increases more rapidly, or for a longer time, or both, than does the length of the head and body. Osgood (1909:148) indicated that in $P . b$. attwateri the tail is 104 per cent of the length of head and body. Shorter tail (mean length) in the holotype and paratypes was one character used by Long (1961:101) to distinguished cansensis from attwateri. He thought that in cansensis the tail was only 91 per cent of the length of head and body. Actually, this was because Long included 15 subadults in his sample of 26 individuals. As can be seen in Figure 1, inclusion of measurements of subadults with those of adults in a sample of $P$. boylii could result in an erroneous impression of relative length of tail in either age category. The tail in $P$. boylii does not reach maximum length until after the length of the head and body has done so (see Figure 1).

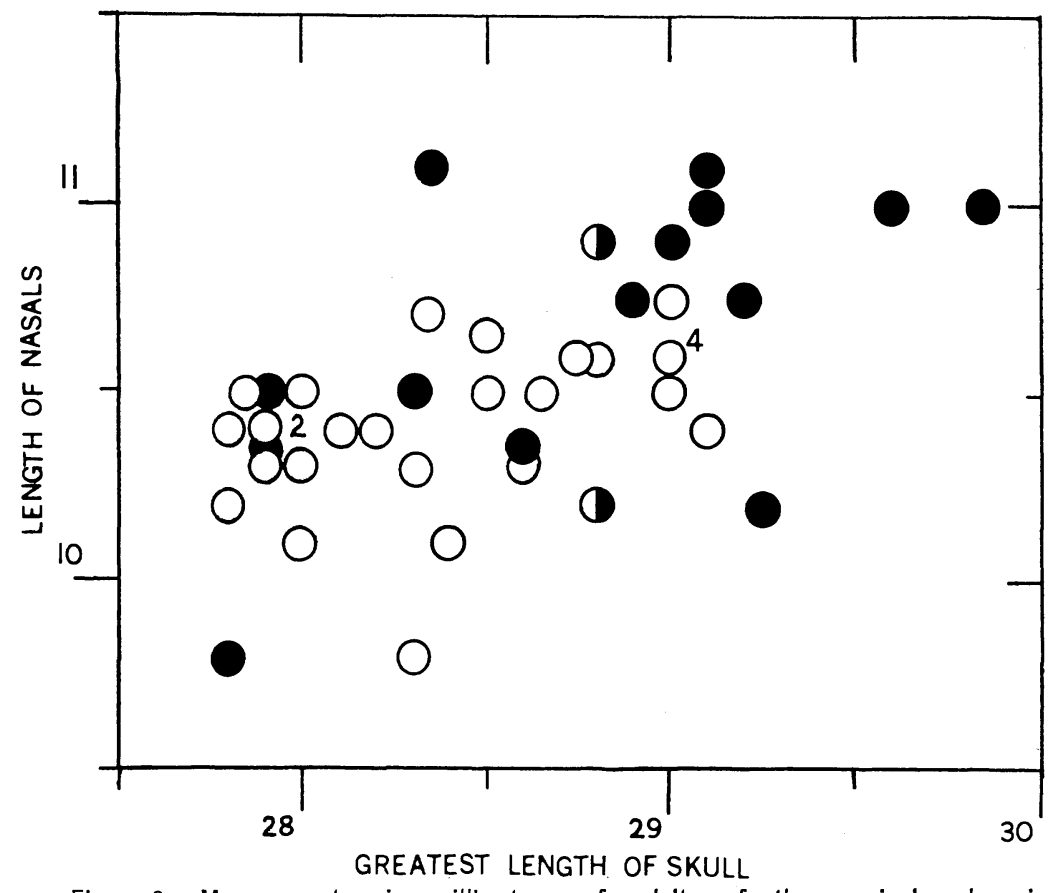

Figure 2. Measurements, in millimeters, of adults of the nominal subspecies Peromyscus boylii cansensis (solid circles) and of P. b attwateri (open circles). Circles that are one-half solid represent one specimen of each subspecies. Numbers indicate more than one specimen represented by circle. 
We have shown that crania of adults of attwateri and cansensis are essentially the same size. The generally accepted criterion as stated by Mayr et al. (1953:142) is that two populations represent different subspecies if the difference between the means of their measurements is more than twice the sum of the standard errors. On this basis, it can be seen (Table 1) that there are no noteworthy differences between our samples of attwateri and cansensis. Furthermore, analysis of measurements (see Table 1) does not reveal any trend in geographic variation that justifies placing specimens of Peromyscus boylii from south-central Kansas in a subspecies different from $P . b$ attwateri.

There is some geographic variation in color of $P$. boylii attwateri. Populations in eastern Kansas and eastern Oklahoma on the one hand are darker than those 530 miles southwest in the more arid south-central Texas. On the basis of dark color, Bangs (1896:137) gave the name Peromyscus bellus to specimens of brush mice from east-central Oklahoma. Osgood (1909:149) realized that northern populations of attwateri were slightly darker than southern populations. He pointed out that the name bellus had been given to specimens representing the extreme differentiation from Peromyscus boylii rowleyi (Allen), the subspecies found farther southward; but this differentiation already is well established at the type locality of attwateri. Furthermore, Osgood (loc. cit.) stated that the recognition of both attwateri and "bellus" would make attwateri an extremely slight and practically indefinable intermediate between rowleyi and "bellus." Recognition of cansensis would have the same effect on attwateri as would recognition of "bellus." In fact, we do not know of any feature on the basis of which cansensis differs from attwateri except in slightly darker average color.

It has been demonstrated adequately that the occurrence of $P$. boylii depends on the presence of suitable habitat (Blair, 1938:521 and 1939: 122; Brown, 1964:189-202; and others). Because steep, rocky bluffs are lacking in much of Kansas, Long (1961:103) suggested that brush mice from cliffs along tributaries of the Caney River in Chautauqua and Cowley counties are isolated from populations of $P . b$. attwateri in Oklahoma and southeastern Kansas by more than 80 miles of grassland. Actually, suitable habitat for $P$. boylii occurs from Chautauqua County, Kansas, for a considerable distance southward into Oklahoma in the drainage area of the Caney River system. Specimens of attwateri have been obtained by one of the authors (Choate) from cliffs overlooking a tributary of the Caney River about 25 miles south of the type locality of cansensis. It seems, therefore, that populations of $P$. boylii in southcentral Kansas are less effectively isolated from populations of brush 


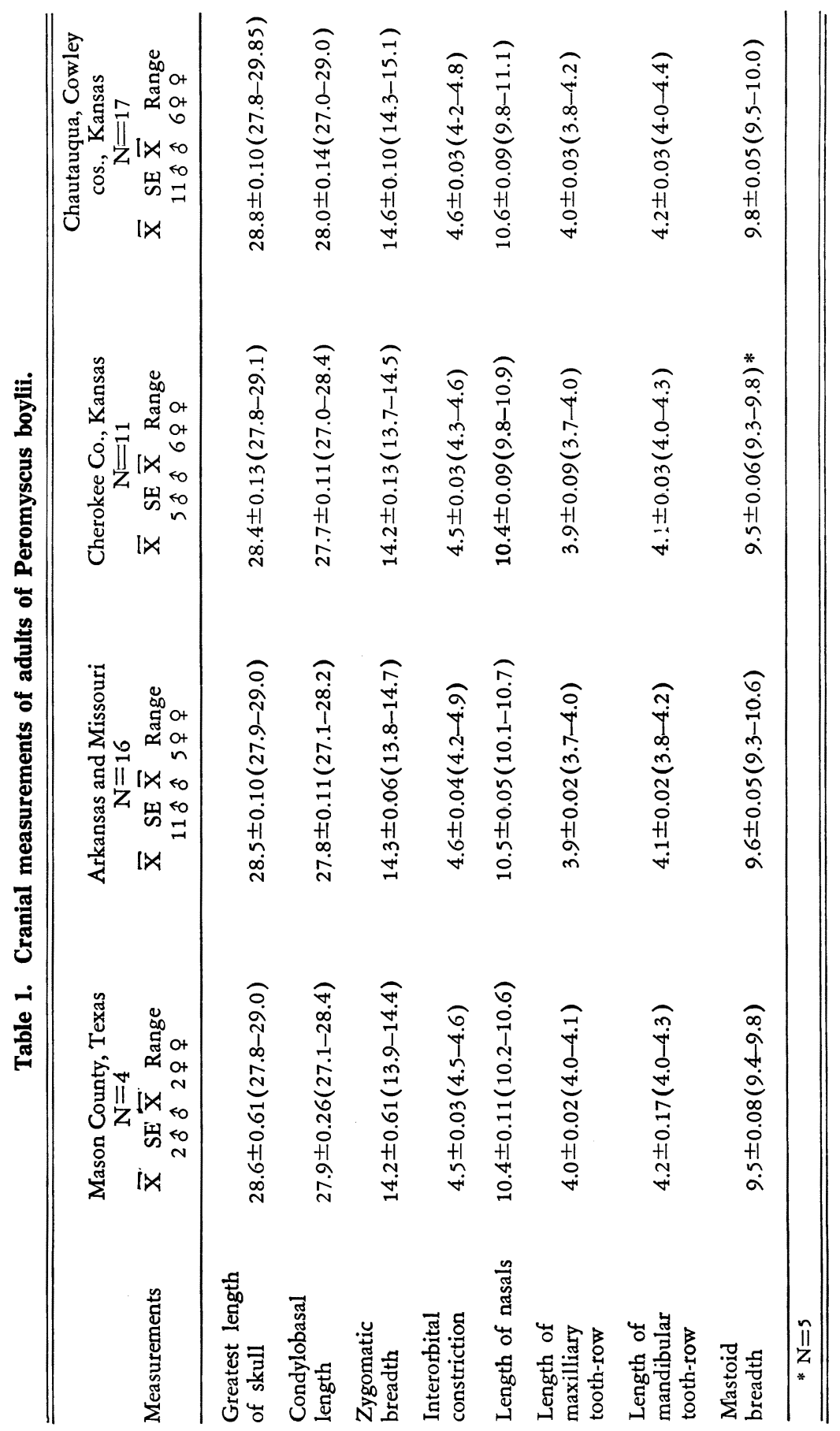


mice in Oklahoma than formerly was supposed. It is likely that all populations of brush mice in Kansas had a common area of origin in eastern Oklahoma.

Long (1961:101) considered lesser protuberance of eyes in cansensis to be a character of taxonomic worth distinguishing cansensis from attwateri. In two adult males of cansensis that we captured on 18 June 1966 and sacrificed on 22 August 1966 and in one adult male of attwateri that we captured on 19 June 1966 and sacrificed on 22 August 1966 , we could not detect any difference in the protuberance of the eyes in life or when the specimens were skinned. Difference in protuberance of eyes conceivably could be related to a difference in nutritional or hormonal physiology, either in captive individuals or in wild individuals living in different environments, but might well fluctuate in the lifetime of the same individual. If such were the case, the difference hardly would be of subspecific worth.

The revised synonomy of Peromyscus boylii attwateri J. A. Allen is as follows:

1895. Peromyscus attwateri J. A. Allen, Bull. Amer. Mus. Nat. Hist., 7:330, November 8. Type locality, Turtle Creek, Kerr County, Texas.

1906. Peromyscus boylei attwateri, V. Bailey, Proc. Biol. Soc. Washington, 19:57, May 1.

1896. Peromyscus bellus Bangs, Proc. Biol. Soc. Washington, 10:137, December 28. Type locality, Stilwell, Adair County, Oklahoma.

1905. Peromyscus boylei laceyi V. Bailey, N. Amer. Fauna, 25:99, October 24. Type locality, Turtle Creek, Kerr County, Texas.

1961. Peromyscus boylii cansensis Long, Univ. Kansas Publ., Mus. Nat. Hist., 14:101, December 29. Type locality, 4 mi. E Sedan, Chautauqua County, Kansas.

Specimens examined (116, KU unless otherwise noted).-KANSAS: 5 mi. S, 2 mi. E Dexter, Cowley Co., 1; 31/2 mi. W Cedar Vale, in Cowley Co., 1; Cedar Creek, 3 mi. W Cedar Vale, in Cowley Co., 13; sec. 18, T. 34 S, R. 8 E, Cowley Co., 2; 4 mi. E Sedan, Chautauqua Co., 9; 2 mi. N Peru, Chautauqua Co., $1 ; 1 \mathrm{mi} . \mathrm{N}, 21 / 4 \mathrm{mi}$. W Elgin, Chautauqua Co., 58; Shimmerhorn Park, 2 mi. S Galena, Cherokee Co., 13 (3 KSC). MISSOURI: $\mathrm{N}$ bank Elk River, $1 / 2 \mathrm{mi} . \mathrm{N}, 4 \mathrm{mi}$. W Noel, McDonald Co., 1; 4 mi. $\mathrm{N}$ Branson, Taney Co., 1. ARKANSAS: $1 \mathrm{mi} . \mathrm{S}$ 
Winslow, Washington Co., 1; 3 mi. S Winslow, Washington Co., 2; 4 mi. SE Marcella, Stone Co., 1; Ozark, Franklin Co., 4; 6 mi. N, 3 mi. E Mena, Polk Co., 4. TEXAS: 3 mi. W Mason, Mason Co., 4.

BANGS, O.

\section{Literature Cited}

1896. Some new mammals from Indian Territory and Missouri. Proc. Biol. Soc. Washington, 10:135-138, December 28.

BLAIR, W. F.

1938. Ecological relationships of the mammals of the Bird Creek Region, northeastern Oklahoma. Amer. Midland Nat., 20:473-526, 12 figs., 3 tables, November.

1939. Faunal relationships and geographical distribution of mammals in Oklahoma. Amer. Midland Nat., 22:85-133, 1 fig., 2 tables, July.

BROWN, L. N.

1964. Ecology of three species of Peromyscus from southern Missouri. Jour. Mamm., 45:189-202, 3 figs., 4 tables, 3 pls., May 20.

HALL, E. R.

1946. Mammals of Nevada. Univ. California Press, Berkeley, xi +710 pp., frontispiece, 485 figs., 11 pls., July 1.

Hall, E. R. and K. R. Kelson

1959. The mammals of North America. Ronald Press, New York, 2:viii + 547-1083 + 79, illustrated, March 31.

HOFFMEISTER, D. F.

1951. A taxonomic and evolutionary study of the pinon mouse, Peromyscus truei. Illinois Biol. Monog., 21:x + 1-104, 24 figs., 7 tables, 5 pls., November 12 .

Long, C. A.

1961. Natural history of the brush mouse (Peromyscus boylii) in Kansas with description of a new subspecies. Univ. Kansas Publ., Mus. Nat. Hist., 14:99-110, 1 fig., December 29.

MAYR, E., E. G. LINSLEY, and R. L. USINGER

1953. Methods and principles of systematic zoology. McGraw-Hill Book Company, Inc., New York, ix + 336 pp., illustrated.

OsGood, W. H.

1909. Revision of the mice of the American genus Peromyscus. N. Amer. Fauna, 28:1-285, 12 figs., 8 pls., April 17.

RIDGWAY, R.

1912. Color standards and color nomenclature. Washington, D. C., Privately printed, iv + 43 pp., 53 pls.

-Museum of Natural History, The University of Kansas, Lawrence. Transmitted August 30, 1966. 